\title{
Factor Effecting of Durian Innovation Product of SME Industry: Study in South of Thailand
}

\author{
Thammarak Srimarut $^{1} \&$ Witthaya Mekhum ${ }^{1}$ \\ ${ }^{1}$ Faculty of Industrial Technology, Suan Sunandha Rajabhat University, Bangkok, Thailand \\ Correspondence: Thammarak Srimarut, Faculty of Industrial Technology, Suan Sunandha Rajabhat University, \\ Bangkok, Thailand. E-mail: Thammarak.sr@ssru.ac.th
}

Received: July 17, 2020

doi:10.5430/rwe.v11n6p38
Accepted: September 4, 2020

Online Published: September 23, 2020

URL: https://doi.org/10.5430/rwe.v11n6p38

\begin{abstract}
Innovation is a process of creating new things or simply a new idea. Innovation helps the organization to find a competitive edge for survival. Innovation improves the quality of existing products like durian products in Thailand. The purpose of the current study is to investigate the link between factors that affect the durian product innovation in the small and medium industries working in the south of Thailand. Respondents of this study are employees working in the SME industry of the south of Thailand. Data is collected through a questionnaire via e-mail. Data is cross-sectional and the study is quantitative. Results generated from PLS revealed that factors that affect the durian product innovation are customer base, department of research and development and level of competition has a positive significant impact on durian product innovation. Technological innovativeness also has a positive significant impact on durian product innovation and also mediates the relationship between the level of competition and durian product innovation in the SME industry of the south of Thailand. Policymakers should focus on these factors for increasing the innovation of durian products.
\end{abstract}

Keywords: eurian product innovation, customer base, research and development, level of competition, technological innovativeness

\section{Introduction}

Innovation in the workplace is important. Innovation at workplaces gives a competitive edge to companies for survival in this competitive global market. Innovation is something new and creative at workplaces in processes, in production, and in products. Innovation gives better or bigger opportunities and makes things faster. Innovation increases the productivity of the organization and reduces the operation and production cost. Products and goods that are made by new innovative processes give better quality and better performances and profit. This innovation at the workplace increase the production level range added more value to products, improved staff retention, motivation, loyalty, and engagement at workplaces. In all other sectors innovation is also important in fruit production in the global market (Dangelico, Pujari, \& Pontrandolfo, 2017).

Like other countries that might be used innovation systems in their organizational process and procedures. Thailand also used innovation processes in its business, especially in the production of durian fruit. Because this durian fruit is export in other countries. For exporting durian products, it's necessary to innovate the process and take a competitive advantage on their competitors. For this purpose, this study conducted to find out the factors that affect the durian product innovation in the SME industry of the south of Thailand. Innovation is an important factor used by Thailand policymakers in their process and in their durian fruit because production and exportation of durian products are gradually decreased (Kuncoro \& Suriani, 2018). 


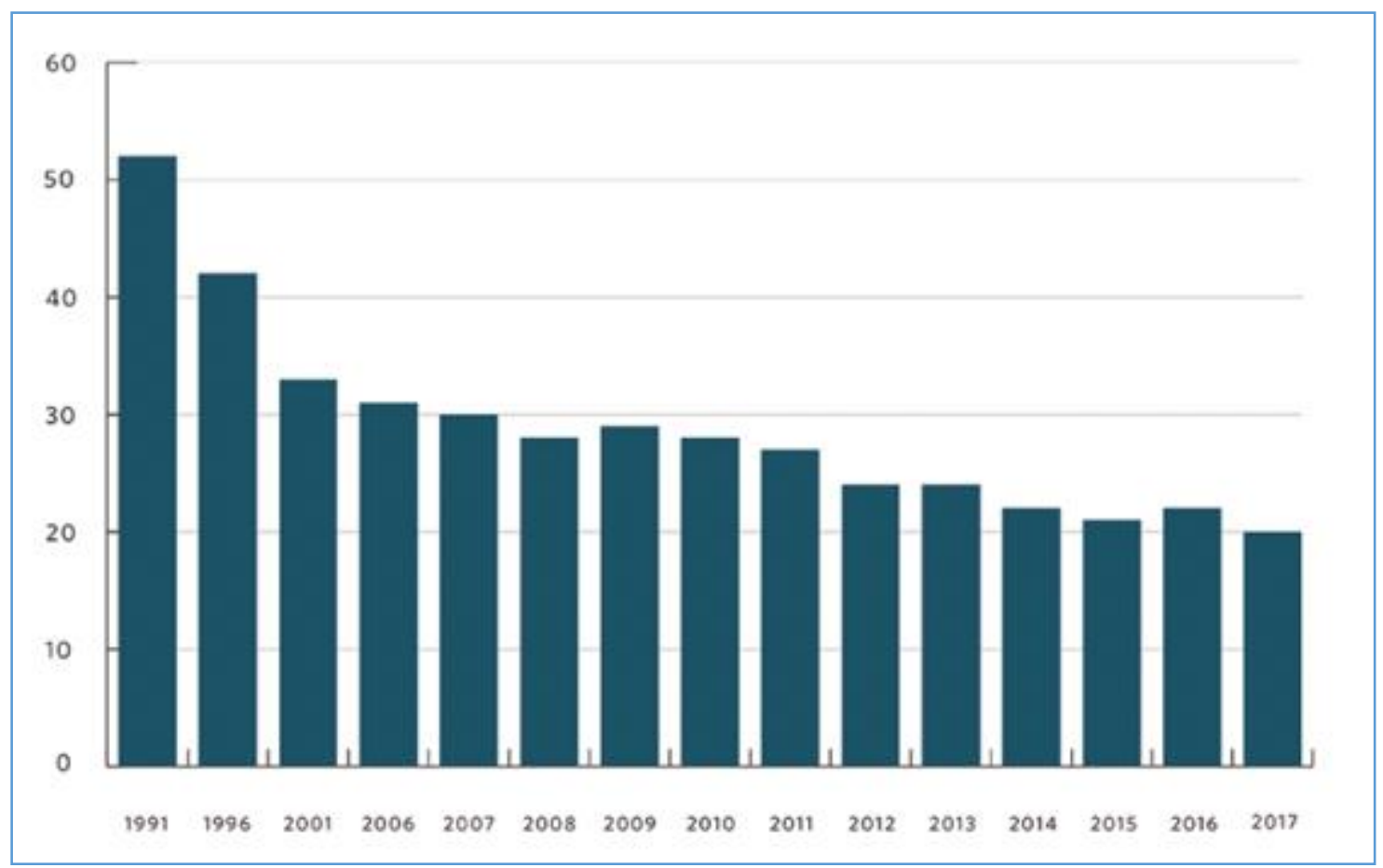

Figure 1. Innovation in SME outlook (2019)

This innovation in the process of durian production facing many challenges in the Thailand SME industry showed in Figure 1. Various challenges like firms or SME industry that working in Thailand has low innovative and technical capabilities. Thai SME companies also don't have good research and development department so these companies not properly engaged in innovative procedures. Companies working in Thailand operate according to traditional Thai perspectives and traditions. These Thai traditional operational perspectives do not encourage innovative and technological capabilities (Markovic \& Bagherzadeh, 2018). Due to these reasons' competitors of Thai durian fruit-producing good quality durian and export it to a major exporting partner of Thailand.

Literature argued that, in the era of this competitive global market, companies focus on innovative processes and gain a competitive edge on competitors for surviving in this era. Companies of Thailand also should focus to innovate because prior studies argued that factors that affect the innovation including customer base, level of competition, and best department of research and development (Melander, 2017). Literature argued that innovative process makes the product on low cost according to the needs and demands of the customer. This process increases sales and profit. Like this customer base variable other related variables like level of competition and best research and development department increase innovation (Mitrega, Forkmann, Zaefarian, \& Henneberg, 2017).

This study is an important contribution to previous literature by finding out the factors that affect the innovation of durian products in the SME industry of the south of Thailand. Literature evident that limited studies were conducted on finding the factors that affect the durian product innovation and in these studies SME industry of Thailand was missing (Najafi-Tavani, Najafi-Tavani, Naudé, Oghazi, \& Zeynaloo, 2018). Moreover. Various studies conducted in durian product innovation in Thailand but they were missing in finding the factors that affect the durian product innovation in the SME industry of the south of Thailand. So, this study has a major theoretical contribution to previous literature. From a practical point of view, this study gave recommendations to policymakers that they increase the technical capabilities of firms and also adopt new operational tactics rather than Thai traditional operational tactics for increasing innovation and also focus on these discussed variables. Because an increase in innovation also increases the production, exporting, and profit of the SME industry that working in the south of Thailand.

\section{Literature Review}

Thailand is a developing country and generates lower middle income but has an open economy system. From the nineties, Thailand considered the fastest growing economy. But many businesses operate according to the Thai 
traditional perspective and mindset. Limited technical capabilities are present in domestic and Small and medium enterprises. So, big operation and production mostly are done by foreign companies (Severo, de Guimarães, \& Dorion, 2017). Due to this gap and low linkage in foreign and in the Thai domestic and SME industry, foreign countries reluctant to link with the Thai SME industry. But nowadays many multinational enterprises linked with the Thai domestic market and support and share knowledge to industry working as Thai domestic organizations and as SMEs. Growing demand and an increase in GDP due to the SME industry local government of Thailand think to support and promote the SME industry. Due to the global competition in the market, the Thai government thinks to increase knowledge-based SME industries. Dynamic, vibrant, and self-motivated promotional plans ate created by the Thai government to increase production in SME (Zaefarian, Forkmann, Mitręga, \& Henneberg, 2017). For this purpose, policymakers should also want to increase innovation in the processes and production of SME. Due to this reason, the current study wants to find out the factors that affect innovation in SME. Some factors and their link are provided below given Figure 2 .

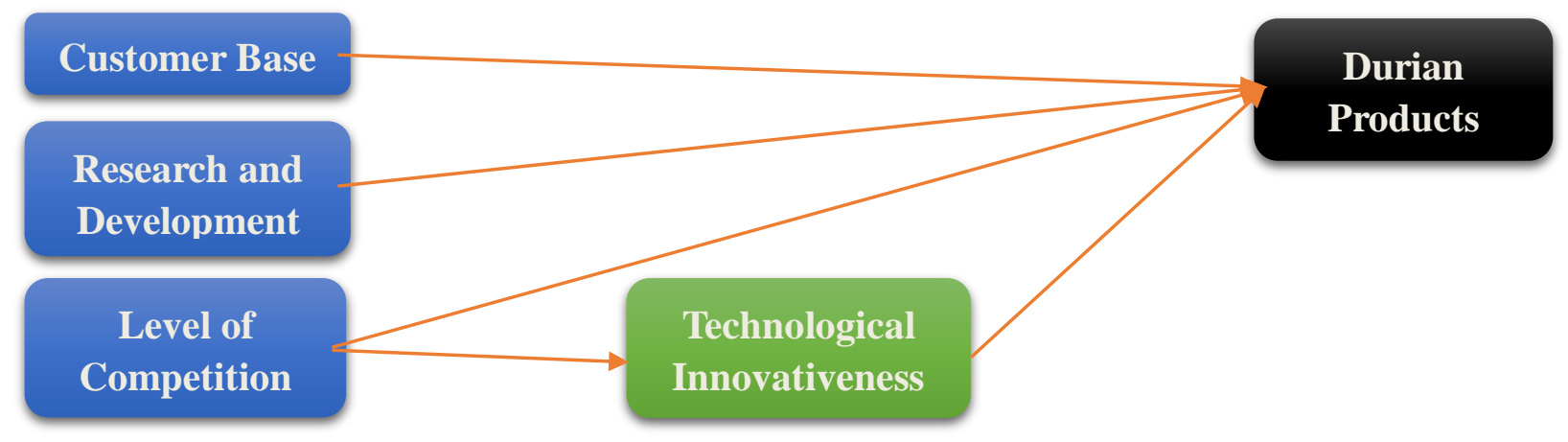

Figure 2. The theoretical framework of the study shows the relationship between factors that affect the Durian product innovation

\subsection{Customer Base and Durian Product Innovation}

Customers are the main source of income for companies. End-users of product and consumers generate revenue for the companies that provide the products. Customer base products act as a competitive advantage for companies because customer purchases those products that according to their needs and demands. Product base on the customer perspective, needs, and wants are generated a large number of revenues for companies. Companies produce customer base product whose research and development department are more efficiently and effectively work (Asadinejad, Rahimpour, Tomsovic, Qi, \& Chen, 2018). Customer base strategies are used to make the link between customer, company, and product. These strategies are used to attract the customer and to make the link between customer and product by increasing the quality of the product, by giving discounts and the main point is to make the product after research on the wants and needs of customers. Because customer purchases only those products which fulfill their needs and which is according to their requirements. Customer needs are sometimes low prices, convenient availability of product, design, reliability, and performance.

Customer base making product strategies in business increases innovation capabilities. As customer wants the low prices and quality products, for making these types of low-cost quality products, production system innovation is necessary. Because new trends in production decrease the fixed and operating cost incurred in the production of low-cost products. Making low cost and quality product increase innovation in organizations. Customer base products include the branding and design of the product. For making good branding and competitive product design for customers, companies need to install the competitive new technological and innovative machines that increase the innovation of businesses (Čierna, Barrientos, Agrasar, \& Arriaza, 2018). Previous literature argued that customer base production in the organization increases the innovation and innovative process in organizations. Previous studies also argued that an innovative customer base product making process has four steps in it. Namely, requirements elicitation, requirements evaluation, requirements translation, and scheme generation. According to this process, on one number stage process, needs, and requirements of the customer by effectively working research and development department. 
After it, in second step requirement of customer and consumers are evaluated and after it making strategies that are according to the customer base product designing and quality produced.

Studies argued that customer base product making strategies increase innovation in organizations. The study conducted on the manufacturing industry of Wuhan china, a sample of 225 is collected from the manufacturing industry and results revealed that there is a positive significant impact of customer base product making has positive significant impact on innovation. Increase in development and production of products according to requirements of customers increase in innovative capabilities of companies (Dew \& Ansari, 2018). These results are proved from the study conducted on the clothing industry of Malaysia. Literature proves that positive significant impact of customer base products on durian product innovation. So, the formulated hypothesis is:

H1: Customer base has a significant impact on durian product innovation

\subsection{Research and Development and Durian Product Innovation}

Research and development, spillovers, innovation systems, and causes the growth of performance. Many regional studies have been conducted related to research and development as part of innovation and growth. A study on the impact of innovation on regional performance in Europe has fundamentally followed different approaches. The analysis has given the link between investment in research and economic growth. Other researches have been conducted in this regard some of the researches are conducted to explain the importance of R \& D. Today most of the large firms have their own R\&D department. Some of the researches are conducted to identify the problems of the organization some are to innovate the processes or products (Abbas, Butt, Masood, \& Javaria, 2019; Abdul-Kahar, Ebi, \& Nasser, 2019; Abdullah \& Siddiqui, 2019; Giannopoulos, Vagenas, Noutsos, Barzouka, \& Bergeles, 2017).

Although science and businesses are different operations of business produce data of scientific interest. According to Edward Ames businessmen are willing to pay to researchers to find out them the answer to certain questions. Work that product liability ideally should promote efficient levels of product safety, but struggle in the wrong direction may decrease the inventions. Studies have been conducted for the different solutions of a business. The objective of this paper is to find the link between research and development with the innovation of the product. Innovation policy is increasingly informed from the perspective of a national innovation system. Many researches emphasize the national interest of the countries and policies. In business organizations research also focuses to compete in the market. New researches are conducted to find the requirements of customer than products are developed according to their requirements with innovation. In the modern era, the customer is curious about the innovations (Goswami, Nandi, \& Chatterjee, 2019). Businesses compete on the base of service providing and specifications of a product. Research and development facilities are provided to the customer. As the $R \& D$ focuses the product for innovation it improves every time.

The supplier also involves in product development and innovation. Some of the researches have concluded that customer input is necessary for product development. Every step of the product innovation involves research and development. Innovation. Innovation involves improving the method of working, producing goods, or improving the goods with new facilities. Often it will involve better technology or better methods of working. Innovation may be the result of Research \& Development. Innovation is based on the R\&D. Similar to many other products durian is also a product of SME (Kim, 2017). Durian is exported from Thailand, Research and development are applied to innovate the durian. In south Thailand how this durian is innovated by the R\& D to find out this effect given hypothesis is developed.

H2: Research and development have a positive significant impact on durian product innovation.

\subsection{Level of Competition, Technological Innovativeness, and Durian Product Innovation}

The relationship between competition and innovation is considered as a complex and tough relationship. Innovation is a key growth indicator and as wells as considered as the firms' key to success. Innovation is the process in which companies transform the brand-new ideas into improved products, processes, and services. Competition is simply the competitive environment between the companies that provided the same products and substitutes for products. Previous studies proved that innovation affects the level of competition in the organization by making the blue oceans, blue oceans means one company left from the competitive environment, and target the new market by innovating their products and emerged as the monopolist in new markets. Innovation also affects the competition in that way companies compete and make the red ocean like compete in the existing competitive market but compete beyond the margins by using innovation. If a relationship exists and proved, then it would be helpful in decreasing the competition between the competitors and increase economic growth (Krolikowski \& Yuan, 2017). 
Many previous studies proved the negative relationship between innovation and competition. As studies argued that for becoming innovative and for innovating the process and products many costs incurred on technological innovativeness. Fighting in the competitive market or by facing a large number of competitions, it is less profitable to incurred costs on innovation rather than on competition. By an increase in innovation also decrease the competition in that way, when companies innovate themselves, innovate their processes and procedures, they are moved from a competitive market. They create a Blue Ocean or target the new markets and left the competition.

Some previous studies argued that $\mathrm{u}$ shape inverted relationships exist in innovation and competition. No positive liners and no negative liner relation exist between them. Various studies are also argued that positive linear relationship is resent in innovation and competition. Companies take more benefits from the competition when they are more innovative than their competitors. This competition in organizations increased innovation. Another way studies also argued that when companies are fighting in a competitive market they want to innovate themselves for survival (Lam, DeCarlo, \& Sharma, 2019). Due to this contradictory result on the relationship between competition and innovation. This study is conducted and formulated a hypothesis is:

H3: Level of competition has a positive significant impact on durian product innovation

It's the age of competition. Each firm tries to go ahead than the others. Without completing the market forces, it looks impossible for firms to exist in the market. Firms are very concerned about competitive forces. In an earlier time when there were few firms in each industry, the competition was very low. After the industrial revolution of the 1700s, many new industries stepped into the market. Each firm tries to capture the customer and wants to retain it for a long time. The objective of each firm is to maximize its profits by selling its goods or services. In this regard customer is the key that will be a source of revenue from each firm. There have been many researchers conducted to find ways to attract and retain the customer (Marakanon \& Panjakajornsak, 2017).

A customer always looks for its benefits. Customer is concerned about the specifications, innovations in the product at a low cost. A study in Turkey has also given a conclusion as a customer will look for the specification against cost, the loyalty of customer comes later. There is competition among the firms for which a customer is concerned. There have been examined many factors to compete with firms. A study of Broad Zen 2009 has analyzed the services provided to the customer are important for competition. In another study by the business school of Wilmington has mentioned that after-sale services are the important key to competition. Another study has concluded that characteristics of the product and its quality is very helpful for competition among the businesses. There have been many same studies that have given different key factors to compete.

In a recent era, the main focus of companies as a tool of competition is technology. Technology is making the life of customer and business very easy and fast. It is the best way to compete. Each firm is in the competition to bring new technology to the business process and products that will help them to give a competitive edge. Due to competition from the use of raw material till delivering the product to the customer each segment has been improved technologically. The maximum business is shifting toward online services. Online business is only possible with technological advancement. Now for the sake of competition companies have their own research and development departments. They invest a lot in innovation. A researcher has stated that competition is leading the innovation. Same is true for technology, advancement in technology is increasing the competition. Competition is key to technological innovations. From the current scenario and level of competition for SME, it is also necessary to adopted technology for competition (Nie \& Haryadi, 2017). Durian is a product of SME how its competition among fruit industry is advancing the technology to check this relation designed hypothesis is given below

H4: The level of competition has a positive significant impact on technological innovativeness.

It is not self-evident that economists ought to engage in the task of explaining the characteristics of technological innovations. It is still considered not enough to say that development and inventive activities are related to the structure of businesses. Each product of the large and small sector are now required technology for their competitiveness. Small enterprises are also exposing to the latest technology. Even small businesses cannot compete without the help of technology. According to Schumpeter, it is important to understand the importance of innovation. Inventions need concentration until they become part of practices (Martínez-Román \& Romero, 2017). All levels of firms can participate in inventions. Sometimes inventions are not planed that may happen accidentally. After all inventions technology has a critical role Thus, the analysis gives prior character to innovation.

According to FINEP when it is required to the technological innovation it can not only be the one reason, the same is presented at the level of four possibilities, namely: product, process, business way, and organizational form. Except the technological innovation, it can be categorized as incremental or radical. Incremental technological is the advancement 
of the already existing technology. It means if there is already a technology being used, improvement in previous will be an increment. Another option is the radical technology which is not the same as the previous one it may consist of some variation to the existing one. Innovation is related to both.

For the durian product of SME, it is exported to different countries with a chain of activities. These operations are being improved from a longtime of the span. Technology is performing its role to make the durian innovative with technology from the supply chain to the delivery of the product. Innovativeness of technology is proven from previous researches as innovations for the product. It is concluded that the innovation of the product is led by technology. Innovation and competitiveness are related positively. It has been proved for the manufacturing sectors of different industries (Karahoca, Karahoca, \& Aksöz, 2018). For durian, this relation may also expect the same. In south Thailand to test this relation for durian hypothesis is derived as:

H5: Technological innovativeness has a positive significant impact on durian product innovation.

In recent years, many scholars have been searching for a useful method to explore the relationship between technological innovation and competitiveness. To be a strong competitor it is necessary to know the innovation and performance of the market in a similar industry. The level of competition must be observed for a healthy competition. It is suitable to perceive that, the spillover benefits for others of a good performance in one product tend to outweigh the costs of that good performance for others. In Thailand, attempts have been done on the national level to increase technological innovation in the durian business. Technological innovations are a result of the competition in processes (Obeng \& Mkhize, 2017).

When looking in Thailand, competitiveness for durian has got a considerable range in technology. It is about the way in which the pattern of international trade evolves over time to reflect changing patterns of capabilities and hence competitive advantage. Posner in his work has also claimed that technology can bring change and improve productivity with innovations. The level of competition is the image of a market that how the market is using the technology. Market comparison is focused on inventions (Camilleri \& Camilleri, 2017). When products compete their characteristics and specs are improved in different aspects. Products are improved by innovations.

There is a positive relationship between competition and product innovation. The research was conducted in the manufacturing sector of the UK. Similarly, the inventions of competition by technology. It is useful for enterprises that they should develop their products technologically. In the previous discussion, it was found that Technological innovation has a relation with competition and as well as with product innovation. This has been proved for the manufacturing and service sectors. No research has found with technological innovation as a mediator of the level of competition and product innovation. This study is addressing the gap for the durian product of SME (Hur, Lee, \& Choo, 2017). A developed hypothesis is given as:

H6: Technological innovativeness mediates the relationship between the level of competition and durian product innovation.

\section{Research Methodology}

Research methodology in the study tells about the description of methods, processes, and procedures used in this study. The study is quantitative in approach. Data is collected from the employees working in the SME industry of south Thailand. Administrated questionnaire on a five-point liker scale was designed. The questionnaire includes some questions related to demographics and some are related to variables and it takes from previous studies. A simple random sampling technique was used. It is an efficient and simple technique of data collection. For collecting the data e-mail address of employees that work in the SME industry of south Thailand was taken from management. The questionnaire was sent via mail by sharing the purpose of the study and giving ensured that data not disclosed to anyone else. After a week filled questionnaire is sent back by respondents.

\section{Data Analysis and Findings}

Measurement model assessment showed the reliability and validity of data. It showed in Figure 3 and Tables 1, 2, and 3. Tables 1 and 2 showed the value of reliability like factor loadings, the value of alpha, composite reliability, and value of average variance extracted (Hair, Hollingsworth, Randolph, \& Chong, 2017). Table 3 showed the values of cross-loadings and it is used for analyzing the validity of data. All values of reliability and validity are in the accepted range. 


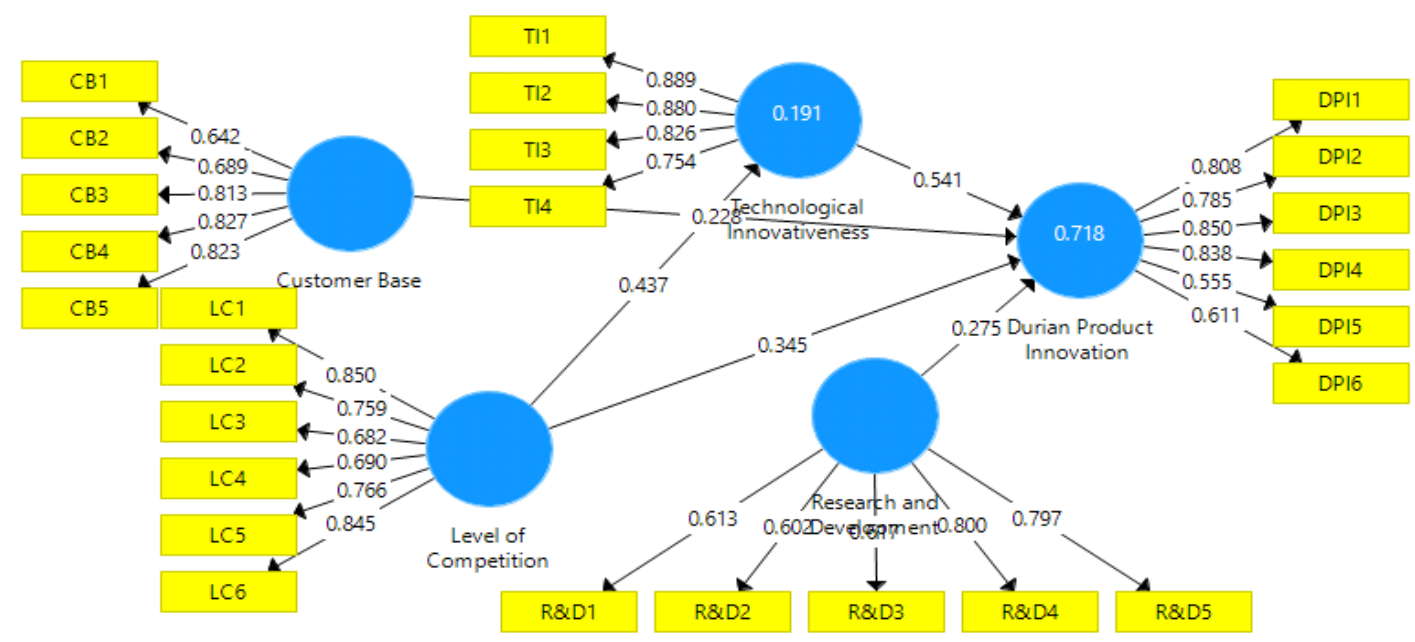

Figure 3. Measurement model

Figure 3 also showed the adjusted R square and its values are 0.718. According to Chin (1998), this impact of $71.8 \%$ is strong.

Table 1. Factor loadings

\begin{tabular}{|c|c|c|c|c|c|}
\hline & $\begin{array}{c}\text { Customer } \\
\text { Base }\end{array}$ & $\begin{array}{c}\text { Durian } \\
\text { Product } \\
\text { Innovation } \\
\end{array}$ & $\begin{array}{c}\text { Level of } \\
\text { Competition }\end{array}$ & $\begin{array}{l}\text { Research and } \\
\text { Development }\end{array}$ & $\begin{array}{l}\text { Technological } \\
\text { Innovativeness }\end{array}$ \\
\hline CB1 & 0.642 & & & & \\
\hline CB2 & 0.689 & & & & \\
\hline CB3 & 0.813 & & & & \\
\hline CB4 & 0.827 & & & & \\
\hline CB5 & 0.823 & & & & \\
\hline DPI1 & & 0.808 & & & \\
\hline DPI2 & & 0.785 & & & \\
\hline DPI3 & & 0.85 & & & \\
\hline DPI4 & & 0.838 & & & \\
\hline DPI5 & & 0.555 & & & \\
\hline DPI6 & & 0.611 & & & \\
\hline LC1 & & & 0.85 & & \\
\hline LC2 & & & 0.759 & & \\
\hline LC3 & & & 0.682 & & \\
\hline LC4 & & & 0.69 & & \\
\hline LC5 & & & 0.766 & & \\
\hline LC6 & & & 0.845 & & \\
\hline R\&D1 & & & & 0.613 & \\
\hline R\&D2 & & & & 0.602 & \\
\hline R\&D3 & & & & 0.617 & \\
\hline R\&D4 & & & & 0.8 & \\
\hline R\&D5 & & & & 0.797 & \\
\hline TI1 & & & & & 0.889 \\
\hline TI2 & & & & & 0.88 \\
\hline TI3 & & & & & 0.826 \\
\hline TI4 & & & & & 0.754 \\
\hline
\end{tabular}

DP: Durian product Innovation, CB: Customer Base, R\&D: Research and development, LC: Level of Competition, TI: Technological innovativeness 
Table 2. Measurement model results

\begin{tabular}{ccccc}
\hline Customer Base & $\begin{array}{c}\text { Cronbach's } \\
\text { Alpha }\end{array}$ & rho_A & $\begin{array}{c}\text { Composite } \\
\text { Reliability }\end{array}$ & (AVE) \\
\hline Durian Product Innovation & 0.816 & 0.817 & 0.873 & 0.582 \\
Level of Competition & 0.839 & 0.857 & 0.883 & 0.562 \\
Research and Development & 0.861 & 0.858 & 0.896 & 0.59 \\
Technological Innovativeness & 0.732 & 0.765 & 0.818 & 0.509 \\
\hline
\end{tabular}

DP: Durian product Innovation, CB: Customer Base, R\&D: Research and development, LC: Level of Competition, TI: Technological innovativeness

Table 3. Cross-loadings

\begin{tabular}{cccccc}
\hline & $\begin{array}{c}\text { Customer } \\
\text { Base }\end{array}$ & $\begin{array}{c}\text { Durian } \\
\text { Product } \\
\text { Innovation }\end{array}$ & $\begin{array}{c}\text { Level of } \\
\text { Competition }\end{array}$ & $\begin{array}{c}\text { Research and } \\
\text { Development }\end{array}$ & $\begin{array}{c}\text { Technological } \\
\text { Innovativeness }\end{array}$ \\
\hline CB1 & 0.842 & 0.433 & 0.744 & 0.603 & 0.256 \\
CB2 & 0.889 & 0.428 & 0.832 & 0.613 & 0.233 \\
CB3 & 0.813 & 0.435 & 0.662 & 0.572 & 0.453 \\
CB4 & 0.827 & 0.445 & 0.669 & 0.565 & 0.464 \\
CB5 & 0.823 & 0.428 & 0.624 & 0.604 & 0.449 \\
DPI1 & 0.429 & 0.808 & 0.397 & 0.633 & 0.692 \\
DPI2 & 0.391 & 0.785 & 0.358 & 0.588 & 0.661 \\
DPI3 & 0.361 & 0.85 & 0.325 & 0.632 & 0.729 \\
DPI4 & 0.379 & 0.838 & 0.379 & 0.627 & 0.726 \\
DPI5 & 0.641 & 0.855 & 0.741 & 0.585 & 0.31 \\
DPI6 & 0.456 & 0.611 & 0.551 & 0.485 & 0.347 \\
LC1 & 0.68 & 0.436 & 0.85 & 0.62 & 0.252 \\
LC2 & 0.56 & 0.46 & 0.759 & 0.544 & 0.25 \\
LC3 & 0.806 & 0.438 & 0.882 & 0.572 & 0.45 \\
LC4 & 0.82 & 0.447 & 0.89 & 0.574 & 0.471 \\
LC5 & 0.631 & 0.411 & 0.766 & 0.594 & 0.247 \\
LC6 & 0.683 & 0.452 & 0.845 & 0.616 & 0.253 \\
R\&D1 & 0.816 & 0.424 & 0.623 & 0.833 & 0.451 \\
R\&D2 & 0.62 & 0.426 & 0.737 & 0.802 & 0.233 \\
R\&D3 & 0.67 & 0.427 & 0.83 & 0.857 & 0.247 \\
R\&D4 & 0.413 & 0.671 & 0.373 & 0.8 & 0.796 \\
R\&D5 & 0.407 & 0.695 & 0.372 & 0.897 & 0.784 \\
TI1 & 0.448 & 0.675 & 0.383 & 0.696 & 0.889 \\
TI2 & 0.431 & 0.69 & 0.381 & 0.689 & 0.88 \\
TI3 & 0.432 & 0.656 & 0.377 & 0.71 & 0.826 \\
TI4 & 0.328 & 0.651 & 0.322 & 0.546 & 0.754 \\
\hline Prodt & & & & \\
\hline
\end{tabular}

DP: Durian product Innovation, CB: Customer Base, R\&D: Research and development, LC: Level of Competition, TI: Technological innovativeness 
Figure 4 of the structural model assessment showed the link between variables and it is used for analyzing the formulated hypothesis (Agbim, 2019; Henseler, Ringle, \& Sinkovics, 2009). (Ahmad, Febrian, Anwar, \& Herwany, 2019; Ahmad, 2018; Alamirew \& Leykun, 2020; Albassami, Hameed, Naveed, \& Moshfegyan, 2019; Amado \& Choon, 2020; Naveed, Hameed, Albassami, \& Moshfegyan, 2019). By seeing the $\mathrm{t}$ and beta values in below-given Table 4, all hypothesis of indirect effect is accepted and have a positive effect because t-values are above then 1.96 and beta values are positive.

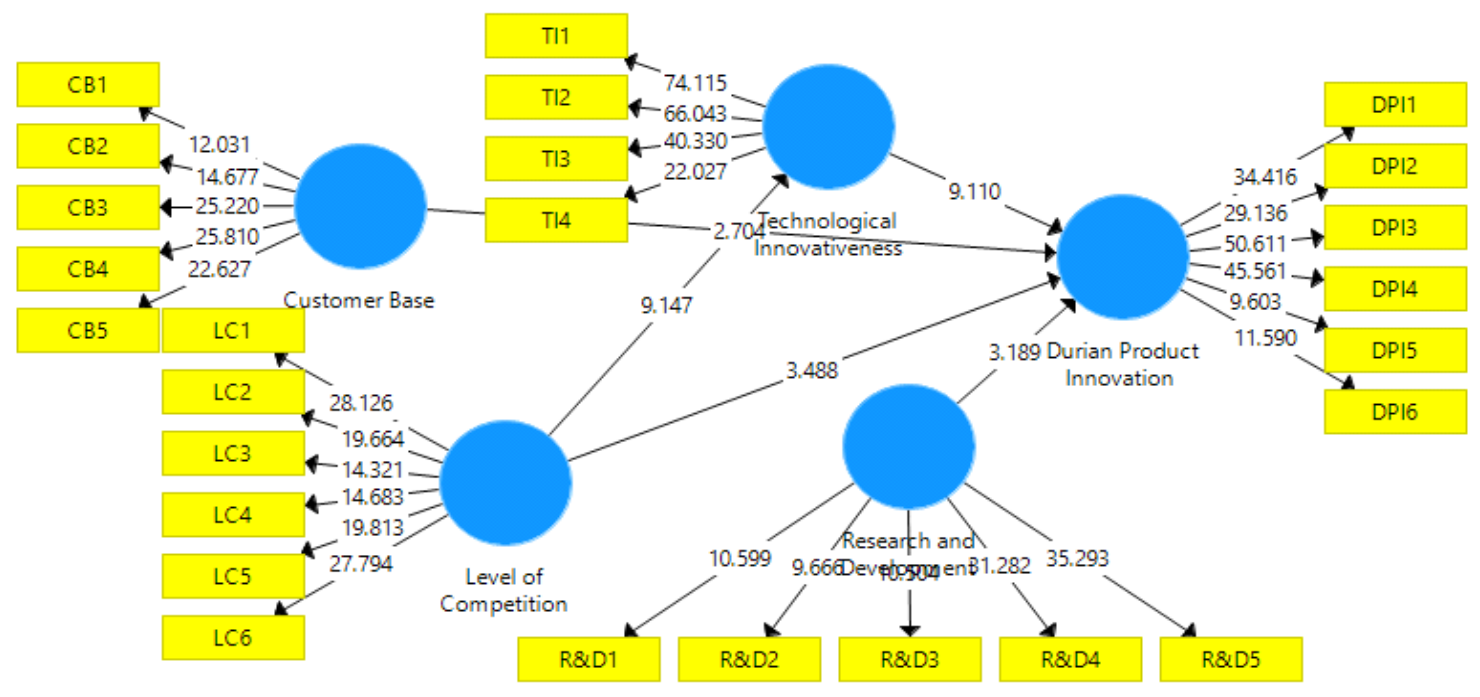

Figure 4. Structural model

Table 4. Direct effect

\begin{tabular}{lccccc}
\hline & $\begin{array}{c}\text { Original } \\
\text { Sample } \\
(\mathbf{O})\end{array}$ & $\begin{array}{c}\text { Sample } \\
\text { Mean } \\
(\mathbf{M})\end{array}$ & $\begin{array}{c}\text { Standard } \\
\text { Deviation } \\
(\text { STDEV })\end{array}$ & $\begin{array}{c}\text { T Statistics } \\
(\mid \mathbf{O} / \text { STDEV })\end{array}$ & $\begin{array}{c}\text { P } \\
\text { Values }\end{array}$ \\
\hline $\begin{array}{l}\text { Customer Base -> Durian Product } \\
\text { Innovation }\end{array}$ & 0.228 & 0.229 & 0.084 & 2.704 & 0.007 \\
$\begin{array}{l}\text { Level of Competition -> Durian Product } \\
\text { Innovation }\end{array}$ & 0.345 & 0.344 & 0.099 & 3.488 & 0.001 \\
$\begin{array}{l}\text { Level of Competition -> Technological } \\
\text { Innovativeness }\end{array}$ & 0.437 & 0.444 & 0.048 & 9.147 & 0 \\
$\begin{array}{l}\text { Research and Development -> Durian } \\
\text { Product Innovation }\end{array}$ & 0.275 & 0.274 & 0.086 & 3.189 & 0.002 \\
$\begin{array}{l}\text { Technological Innovativeness -> Durian } \\
\text { Product Innovation }\end{array}$ & 0.541 & 0.541 & 0.059 & 9.11 & 0 \\
\hline
\end{tabular}

DP: Durian product Innovation, CB: Customer Base, R\&D: Research and development, LC: Level of Competition, TI: Technological innovativeness

Below given Table 5 showed the analysis of the mediation effect of technological innovativeness. In this Table 5 of indirect effect, t-values are greater than 1.96 which means that technological innovativeness has a mediation effect. It also showed in Figure 5. 
Table 5. Indirect effect

\begin{tabular}{lccccc}
\hline & $\begin{array}{c}\text { Original } \\
\text { Sample (O) }\end{array}$ & $\begin{array}{c}\text { Sample } \\
\text { Mean (M) }\end{array}$ & $\begin{array}{c}\text { Standard } \\
\text { Deviation } \\
\text { (STDEV) }\end{array}$ & $\begin{array}{c}\text { T Statistics } \\
(\mid \text { O/STDEV|) }\end{array}$ & P Values \\
\hline $\begin{array}{l}\text { Level of Competition -> } \\
\begin{array}{l}\text { Technological } \\
\text { Innovativeness -> Durian }\end{array}\end{array}$ & 0.236 & 0.24 & 0.034 & 6.886 & 0 \\
Product Innovation & & & & & \\
\hline
\end{tabular}

DP: Durian product Innovation, CB: Customer Base, R\&D: Research and development, LC: Level of Competition, TI: Technological innovativeness

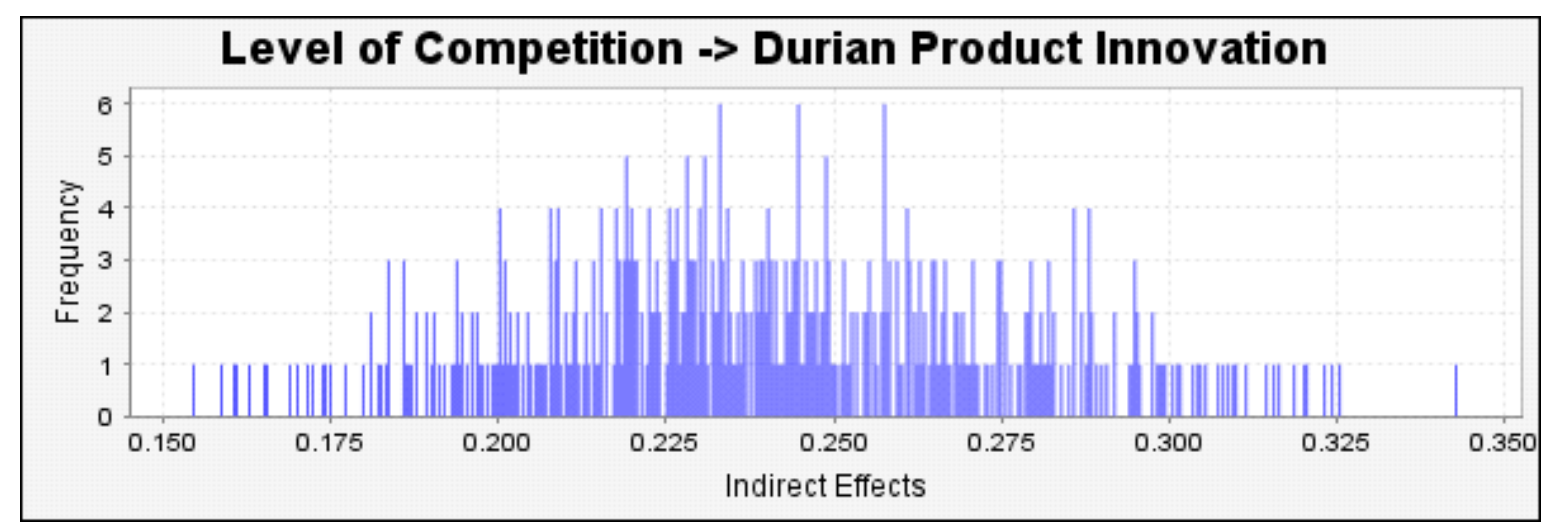

Figure 5. Indirect effect histogram

\section{Discussion}

This current study wants to study the link between factors that affect the durian product innovation in the SME industry of the south of Thailand. Factors that affect innovation of durian production are customer base, level of competition, department of research and design, and technological innovativeness. Participants of this study are employees working in the SME industry working in the south of Thailand. Data is collected through questionnaires via e-mail. After collecting data Smart PLS applied to data or further analysis.

Factors that have a positive significant impact on durian product innovation is customer base. Customer base means the product is according to the needs and demands of customers that increase the effective innovation in the product (Ardito \& Petruzzelli, 2017). Increase in innovation that liked by the users when it made on the basis of the customer base or according to the needs and wants of customers. Second is the research and development department of any organization put substation increase in the innovation capabilities of durian products in the SME industry of south of Thailand.

The third factor that effect the innovation capabilities of durian product in the SME industry working in the south of Thailand is the level of competition. The level of competition is talking about the competition between companies producing the same type of product (Bustinza, Gomes, Vendrell-Herrero, \& Baines, 2019). Increase in the level of competition boost up the business to innovate product for getting a competitive edge. Technological innovativeness also has a positive significant impact on durian product innovation and it also mediates the relationship between the level of competition and innovation of durian products in the SME industry working in the south of Thailand.

\section{Conclusion}

The purpose of conducting this current study is to find out the factors that affect the innovation of durian products in the SME industry of the south of Thailand. These factors including the customer base, level of competition, department of research and development and also the technological innovativeness. Data is collected from the employee working in the SME industry of the south of Thailand. The study is quantitative and data is cross-sectional. Data is collected by simple random and through questionnaires via e-mail method. After data collection, Smart PLS is applied to data for statistical analysis. 
Results indicated that the factors that find out in this study have a positive significant impact on durian product innovation. The customer base, level of competition, and department of research and development have a positive significant impact on durian product innovation in the SME industry of the south of Thailand. Technological innovativeness also increased by an increase in the level of competition and it also has a positive significant impact on durian product innovation. Technological innovativeness also mediates the relationship between the level of competition and durian product innovation in employees working in the SME industry of the south of Thailand. Is might be possible that innovation of durian product increase by increasing the factor like customer base, level of competition, department of research and development and also the technological innovativeness.

\section{Implications}

This current study conducted to examine the link between factors that affect the innovation of durian products in the SME industry of the south of Thailand. These factors including the customer base, level of competition, department of research and development, and also the technological innovativeness in employees working in the SME industry of south of Thailand. This type of study is missing from previous literature. So, this study has a vital contribution to previous studies.

This study has recommendations for policymakers or managers of the SME industry that they should want to focus on this above-discussed factor for increasing the innovation of durian products. Policymakers should focus on the product quality that it should be according to the customer base. Research and development department effectively perform their tasks. Innovate products before competitors for getting a competitive edge on competitors also increases the innovation in the SME industry of the south of Thailand.

\section{References}

Abbas, F., Butt, S., Masood, O., \& Javaria, K. (2019). The effect of bank capital buffer on bank risk and net interest margin: Evidence from the US. Global Journal of Social Sciences Studies, 5(2), $72-87$.

Abdul-Kahar, A., Ebi, S. B. S., \& Nasser, S. M. A. (2019). Conceptualisation of lack of discipline and porobity as the main cause towards good governance practice. International Journal of Public Policy and Administration Research, 6(1), 12-22.

Abdullah, S., \& Siddiqui, D. A. (2019). Working capital financing and corporate profitability of Pakistan manufacturing firms: Evidence from FMCG, cement \& chemical sector. Asian Journal of Economic Modelling, $7(2), 82-94$.

Agbim, K. C. (2019). Corporate governance and firm performance of private family businesses in South Eastern Nigeria. International Journal of Economics, Business and Management Studies, 6(1), 50-76.

Ahmad, L. R., Febrian, E., Anwar, M., \& Herwany, A. (2019). Sensitivity Of depositors To risk of small banks under deposit insurance regime: Evidence from Indonesia. Global Journal of Social Sciences Studies, 5(2), 105-118.

Ahmad, S. D. (2018). Legal protection carried out by the financial service authority in a dispute between consumers and insurance companies in Indonesia. International Journal of Social and Administrative Sciences, 3(1), 55-61.

Alamirew, A., \& Leykun, F. (2020). Determinant of tax revenue effort in Sub-Saharan African countries: A stochastic frontier analysis. International Journal of Sustainable Development \& World Policy, 9(1), 47-71.

Albassami, A. M., Hameed, W. U., Naveed, R. T., \& Moshfegyan, M. (2019). Does Knowledge Management Expedite SMEs Performance through Organizational Innovation? An Empirical Evidence from Small and Medium-sized enterprises (SMEs). Pacific Business Review International, 12(1), 11-22.

Amado, A., \& Choon, L. M. (2020). Impact of changes in exchange rate on stock market: An empirical evidence from Indonesia. International Journal of Applied Economics, Finance and Accounting, 7(1), 24-31.

Ardito, L., \& Petruzzelli, A. M. (2017). Breadth of external knowledge sourcing and product innovation: the moderating role of strategic human resource practices. European Management Journal, 35(2), 261-272.

Asadinejad, A., Rahimpour, A., Tomsovic, K., Qi, H., \& Chen, C.-f. (2018). Evaluation of residential customer elasticity for incentive based demand response programs. Electric Power Systems Research, 158, 26-36.

Bustinza, O. F., Gomes, E., Vendrell-Herrero, F., \& Baines, T. (2019). Product-service innovation and performance: the role of collaborative partnerships and R\&D intensity. R\&D Management, 49(1), 33-45.

Camilleri, M. A., \& Camilleri, A. (2017). The technology acceptance of mobile applications in education. Paper presented at the 13th International Conference on Mobile Learning (Budapest, April 10th). Proceedings, 
International Association for Development of the Information Society.

Chin, W. W. (1998). The partial least squares approach to structural equation modeling. Modern Methods for Business Research, 295(2), 295-336.

Čierna, D., Barrientos, M., Agrasar, C., \& Arriaza, R. (2018). Epidemiology of injuries in juniors participating in top-level karate competition: a prospective cohort study. Br J Sports Med, 52(11), 730-734.

Dangelico, R. M., Pujari, D., \& Pontrandolfo, P. (2017). Green product innovation in manufacturing firms: A sustainability-oriented dynamic capability perspective. Business Strategy and the Environment, 26(4), 490-506.

Dew, R., \& Ansari, A. (2018). Bayesian nonparametric customer base analysis with model-based visualizations. Marketing Science, 37(2), 216-235.

Giannopoulos, N., Vagenas, G., Noutsos, K., Barzouka, K., \& Bergeles, N. (2017). Somatotype, level of competition, and performance in attack in elite male volleyball. Journal of human kinetics, 58(1), 131-140.

Goswami, S., Nandi, S., \& Chatterjee, S. (2019). Sentiment analysis based potential customer base identification in social media. Contemporary Advances in Innovative and Applicable Information Technology (pp. 237-243). Springer.

Hair, J., Hollingsworth, C. L., Randolph, A. B., \& Chong, A. Y. L. (2017). An updated and expanded assessment of PLS-SEM in information systems research. Industrial Management \& Data Systems, 117(3), 442-458.

Henseler, J., Ringle, C. M., \& Sinkovics, R. R. (2009). The use of partial least squares path modeling in international marketing. New challenges to international marketing (pp. 277-319). Emerald Group Publishing Limited.

Hur, H. J., Lee, H. K., \& Choo, H. J. (2017). Understanding usage intention in innovative mobile app service: Comparison between millennial and mature consumers. Computers in Human Behavior, 73, 353-361.

Karahoca, A., Karahoca, D., \& Aksöz, M. (2018). Examining intention to adopt to internet of things in healthcare technology products. Kybernetes.

Kim, Y. H. (2017). The effects of major customer networks on supplier profitability. Journal of Supply Chain Management, 53(1), 26-40.

Krolikowski, M., \& Yuan, X. (2017). Friend or foe: Customer-supplier relationships and innovation. Journal of Business Research, 78, 53-68.

Kuncoro, W., \& Suriani, W. O. (2018). Achieving sustainable competitive advantage through product innovation and market driving. Asia Pacific Management Review, 23(3), 186-192.

Lam, S. K., DeCarlo, T. E., \& Sharma, A. (2019). Salesperson ambidexterity in customer engagement: do customer base characteristics matter?. Journal of the Academy of Marketing Science, 47(4), 659-680.

Marakanon, L., \& Panjakajornsak, V. (2017). Perceived quality, perceived risk and customer trust affecting customer loyalty of environmentally friendly electronics products. Kasetsart Journal of Social Sciences, 38(1), 24-30.

Markovic, S., \& Bagherzadeh, M. (2018). How does breadth of external stakeholder co-creation influence innovation performance? Analyzing the mediating roles of knowledge sharing and product innovation. Journal of Business Research, 88, 173-186.

Martínez-Román, J. A., \& Romero, I. (2017). Determinants of innovativeness in SMEs: disentangling core innovation and technology adoption capabilities. Review of Managerial Science, 11(3), 543-569.

Melander, L. (2017). Achieving sustainable development by collaborating in green product innovation. Business Strategy and the Environment, 26(8), 1095-1109.

Mitrega, M., Forkmann, S., Zaefarian, G., \& Henneberg, S. C. (2017). Networking capability in supplier relationships and its impact on product innovation and firm performance. International Journal of Operations \& Production Management.

Najafi-Tavani, S., Najafi-Tavani, Z., Naudé, P., Oghazi, P., \& Zeynaloo, E. (2018). How collaborative innovation networks affect new product performance: Product innovation capability, process innovation capability, and absorptive capacity. Industrial Marketing Management, 73, 193-205.

Naveed, R. T., Hameed, W. U., Albassami, A. M., \& Moshfegyan, M. (2019). Online Tax System (OTS) in Pakistan: The role of Tax Service Quality (TSQ) and Information Communication Technology (ICT). Pacific Business Review International, 11(12), 78-86. 
Nie, L. K. A., \& Haryadi, S. (2017). Comparison of the Haryadi Index with existing method in competition, equality, fairness, and correlation level calculation: Case study: Telecommunication industry. Paper presented at the 2017 11th International Conference on Telecommunication Systems Services and Applications (TSSA).

Obeng, A. Y., \& Mkhize, P. L. (2017). An exploratory analysis of employees and customers' responses in determining the technological innovativeness of banks. The Electronic Journal of Information Systems in Developing Countries, 80(1), 1-23.

Severo, E. A., de Guimarães, J. C. F., \& Dorion, E. C. H. (2017). Cleaner production and environmental management as sustainable product innovation antecedents: a survey in Brazilian industries. Journal of Cleaner Production, 142, 87-97.

Zaefarian, G., Forkmann, S., Mitręga, M., \& Henneberg, S. C. (2017). A capability perspective on relationship ending and its impact on product innovation success and firm performance. Long Range Planning, 50(2), 184-199.

\section{Copyrights}

Copyright for this article is retained by the author(s), with first publication rights granted to the journal.

This is an open-access article distributed under the terms and conditions of the Creative Commons Attribution license (http://creativecommons.org/licenses/by/4.0/). 